\title{
Borderline Ovarian Serous Adenofibroma
}

National Cancer Institute

\section{Source}

National Cancer Institute. Borderline Ovarian Serous Adenofibroma. NCI Thesaurus.

Code $C 40028$.

A low malignant potential adenofibroma arising from the ovary. It is characterized by an atypical epithelial hyperplasia. The epithelial cells are of serous type. There is no evidence of stromal destructive invasion. 